\title{
MANEJEMEN KINERJA PENYULUH PERTANIAN DINAS PERTANIAN DAN PERIKANAN KABUPATEN INDRAGIRI HULU
}

\author{
AGRICULTURAL EXTENSION MANAGEMENT PERFORMANCE \\ AGRICULTURE AND FISHERIES SERVICE \\ INDRAGIRI HULU REGENCY
}

\author{
Teuku Mursalahuddin, MeliSasmi, Chezy WM Vermila \\ Agriculture Faculty Agribusiness Study Program \\ Kuantan Singingi Islamic University Teluk Kuantan \\ teukumursalahuddin72@gmail.com, melisasmi2011@gmail.com, chezywmvermila16@gmail.com
}

\begin{abstract}
ABSTRAK
Penelitian ini bertujuan untuk mengetahui manajemen kinerja penyuluhan pertanian pada Dinas Pertanian dan Perikanan Kabupaten Indragiri Hulu dalam merencanakan, melaksanakan dan mengevaluasi, untuk mengetahui prestasi kerja penyuluh pertanian dalam merencanakan, melaksanakan dan mengevaluasi program Penyuluhan di Kabupaten Indragiri Hulu.Subjek dari penelitian ini adalah 22orang penyuluh pertanian, yang merupakan penyuluh Pegawai Negeri Sipil dan penyuluh pertanian THL-TBPP Kabupaten Indragiri Hulu, Provinsi Riau.

Metode analisis data menggunakan analisis secara matematik dengan analisis Skala Likert's Summatied Ratting (SLR) dan analisisNilai Prestasi Kerja (NPK).Hasil penelitian dari analisis menunjukan bahwamanajemen kinerja penyuluhpertanian memiliki skor 91,02 dengan kategori baik,pada variabel X1 perencanaan persiapan penyuluhan pertanian mendapat skor 107,75 dengan kategori sangat baik (SB), Variabel kemampuan pelaksanaan penyuluhan pertanian memiliki skor sebesar 86,80 dengan kategori baik (B) sedangkan pada variabel Evaluasi dan Pelaporan adalah memiliki skor 78,50 dengan katagori baik (B). Adapun nilai prestasi kerja penyuluh pertanian memiliki skor 82,72 dengan kategori baik.
\end{abstract}

\section{Kata Kunci : Kinerja; Manajemen; Nilai Prestasi Kerja; Penyuluhan.}

\begin{abstract}
This study aims to determine the performance management of agricultural extension services at the Department of Agriculture and Fisheries of Indragiri Hulu Regency in planning, implementing and evaluating, to determine the work performance of agricultural extension workers in planning, implementing and evaluating Extension programs in Indragiri Hulu Regency. The subjects of this study were 22 agricultural extension workers, who were extension workers of the THL-TBPP Civil Servants and extension workers in Indragiri Hulu Regency, Riau Province.

The method of data analysis uses mathematical analysis with analysis of Likert's Summatied Ratting Scale (SLR) and analysis of Work Achievement Value (NPK). The results of the analysis show that the performance of agricultural extension officers has a score of 91.02 with a
\end{abstract}


good category, in the X1 variable the planning of agricultural extension preparation scores 107.75 with a very good category $(S B)$, the variable ability to implement agricultural extension has a score of 86.80 with a good category $(B)$ while the Evaluation and Reporting variable is a score of 78.50 with a good category $(B)$. The value of agricultural extension work performance has a score of 82.72 in the good category.

Keywords: Extension; Management; Performance; Value of Work Achievement;:

\section{PENDAHULUAN}

\section{Latar belakang}

Sistem Penyuluhan Pertanian berdasarkan undang-undang Republik Indonesia Nomor: 16 Tahun 2006 tentang Sistem Penyuluhan Pertanian, Perikanan dan Kehutanan (SP3K). Pemerintah mengamanatkan bahwa penyelenggaraan penyuluhan menjadi wewenang dan tanggungjawab Pemerintah Pusat dan Pemerintah Daerah. Wewenangdan tanggungjawab pemerintah tersebut diwujudkan antaralain dengan menyelenggarakan revitalisasi penyuluhan pertanian yang meliputi aspek-aspek penataan kelembagaan, ketenagaan, penyelenggaraan, sarana dan prasarana, serta pembiayaan penyuluhan

Manajemen penyuluhan pertanian akan menghasilkan kinerja yang baik apabila mampu melakukanfungsi manajemen penyuluh sehingga akan berdampak kepada perubahan perilaku petani, dengan adanya perobahan perilaku diharapkan dapat peningkatan produksi pertaniansertameningkatnya

kesejahteraanpetani.

Penyuluh pertanian diDinas Pertanian dan Perikanan Kabupaten Indragiri Hulu dalam melaksanakan kegiatan masih memiliki beberapa permasalahan dilihat dari jumlah penyuluh dalam pembagian wilayah kerja tidak sebanding atau memenuhi standar undang-undang nomor 16 Tahun 2006 yaitu 1 desa 1 penyuluh.

Luas wilayah Kabupaten Indragiri Hulu adalah 8.198,26 Km2 (819.826,0 ha) dan memiliki 14 BP3 yang berada pada masing-masing kecamatan serta jumlah desa sebanyak 194 desa, Total penyuluh pertanian 72 orang yang terdiri dari 59 orang penyuluh pertanian Pegawai Negeri Sipil (PNS) dan 13 orang Penyuluh THL-TBPP, jika dibandingkan dengan jumlah desa maka seorang penyuluh rata-rata membina 3 desa binaan.

Jumlah penyuluh yang masih kurang, tingkat pendidikan masih banyak pada tinggkat SLTA, sarana dan prasarana yang kurang memadai akan mempengaruhi tingkat 
manejemen penyuluh pertanian dalam merencanakan melaksanakan dan mengevaluasi kegiatan penyuluhan serta akan mempengaruhi terhadap prestasi kerja penyuluh pertanian. Berdasarkan permasalahan tersebut diatas peneliti tertarik melakukan penelitian tentang "Manejemen kinerja penyuluh pertanian Dinas Pertanian dan Perikanan Kabupaten Indragiri Hulu”.

\section{Perumusan Masalah}

Berdasarkan latar belakang, maka yang menjadi permasalahan pada penelitian ini adalah;

1. Bagaimana tingkat manajemen kinerja penyuluh pertanian pada Dinas Pertanian dan Perikanan Kabupaten Indragiri Hulu dalam merencanakan, melaksanakan dan mengevaluasi?

2. Bagaimana nilai prestasi kerja penyuluh pertanian dalam merencanakan, melaksanakan dan mengevaluasi program penyuluhandiKabupaten Indragiri Hulu?

\section{Tujuan Penelitian}

Tujuandari penelitian ini adalah

1. Untukmengetahuitingkatmanajemenki nerjapenyuluhpertanianpadaDinas Pertaniandan Perikanan Kabupaten
Indragiri Huludalammerencanakan, melaksanakandanmengevaluasi,

2. Untukmengetahuiprestasikerjapenyulu hpertaniandalammerencanakan, melaks anakandanmengevaluasiprogrampenyu luhandi KabupatenIndragiriHulu.

\section{Ruang Lingkup}

PenyuluhPertanian yang dijadikan Sampel adalah penyuluh yang berada pada wilayah kerjaDinasPertaniandanPerikanan KabupatenIndragiriHulu.Penilaian manajemenpenyuluhanpertaniandan tingkatprestasikerjadiukurselama 1 tahun yaitu tahun 2018 .

\section{METODE PENELITIAN}

\section{Waktu dan tempat}

$$
\text { Penelitianini }
$$

dilaksanakandi4 (empat)Balai Penyuluhan Pertanian dan Perikanan(BP3)yangberadadibawah naunganDinasPertaniandanPerikanan KabupatenIndragiri Hulu,Waktu pelaksanaanpenelitianiniselama11 (sebelas)bulanyaitumulaidaribulan maret 2018sampaidengan februari 2019.

\section{Metode Pengambilan Sampel}

Kecamatan atau BP3 yang dijadikan sampel kecamatan ditentukan secara purposive dengan memilih 4 Balai Penyuluhan Pertanian dan Perikanan (BP3) pada masing-masing kecamatan yang dipilih yaitu; Kecamatan Batang Peranap, Kecamatan 
Pasir Penyu, Kecamatan Rengat dan Kecamatan Kuala Cenaku. Penentuan Kecamatan /BP3 ditentukan berdasarkan;1) wilayah kecamatan terjauh dari Ibukota Kabupaten, 2) wilayah terdekat dengan ibukota Kabupaten, 3) berdasarkan tingkat penduduk hiterogen

Variabel penelitian pada dasarnya adalah sesuatu yang berbentuk apa saja yang ditetapkan oleh peneliti untuk dipelajari sehingga diperoleh informasi tentang hal tersebut, kemudian ditarik kesimpulannya.
Indikator dari variable penelitian yang membantu kita dalam mengukur perubahanperubahan yang lebih baik secara langsung maupun secara tidak langsung dari waktu ke waktu. Sugiyono (2006)

Adapun variabel manajemen penyuluhan pertanian adalah variabel persiapan penyuluhan pertanian (X1), pelaksanaan penyuluhan pertanian (X2), evaluasi dan pelaporan penyuluhan pertanian (X3) variabel dan indikator tersebut dapat dilihat pada Tabel1.

\begin{tabular}{|c|c|c|c|c|}
\hline Konstruk & Variabel & Label & Indikator & Skor \\
\hline \multirow[t]{12}{*}{$\mathbf{X}$} & \multirow{12}{*}{$\begin{array}{c}\text { X.1 } \\
\text { Persiapa } \\
\quad n \\
\text { Penyuluh } \\
\text { Pertanian }\end{array}$} & X.1.1. Data Potensi & $\begin{array}{l}\text { Penyuluh telah membuat Peta Wilayah, } \\
\text { Peta Potensi Wilayah kerja, Monografi } \\
\text { Wilayah kerja dan membuat Rencana } \\
\text { Kegiatan Penyuluh Desa/RKPD }\end{array}$ & \multirow[t]{12}{*}{$\begin{array}{l}1,2,3 \\
4,5\end{array}$} \\
\hline & & \multirow[t]{2}{*}{$\begin{array}{l}\text { X.1.2. Pengawalan } \\
\text { RDKK }\end{array}$} & $\begin{array}{l}\text { Penyuluh telah memandu membuat } \\
\text { RUK/RUB, memandu membuat RDK, } \\
\text { memandu membuat RDKK dan membuat }\end{array}$ & \\
\hline & & & $\begin{array}{l}\text { RDKK Pupuk bersubsidi sesuai } \\
\text { kebutuhan petani }\end{array}$ & \\
\hline & & \multirow{5}{*}{$\begin{array}{l}\text { X.1.3. Penyusunan } \\
\text { Programa } \\
\text { Penyuluhan } \\
\text { Pertanian didesa } \\
\text { dan kecamatan }\end{array}$} & Penyuluh telah menyusun & \\
\hline & & & Penyuluhan Pertanian Desa/ Kelurahan, & \\
\hline & & & membuat Rekap Programa Penyuluhan & \\
\hline & & & Kelurahan & \\
\hline & & & $\begin{array}{l}\text { Pemeringkatan Masalah, membuat Draf } \\
\text { programa dan Sikronikasi kegiatan } \\
\text { penyululuhan }\end{array}$ & \\
\hline & & & Keadaan Wilayah (Potensi, & \\
\hline & & RKT Penyuluhan & Produktivitas, Lingkungan Usaha & \\
\hline & & Pertanian & Pertanian, Prilaku Petani, dll), & \\
\hline & & & Penetapan Tujuan,Penetapan Masalah & \\
\hline
\end{tabular}


X.2 X.2.1.

$\begin{array}{cl}\text { Pelaksan } & \text { Desiminasi/penyeb } \\ \text { an } & \text { aran Materi } \\ \text { Penyuluh } & \text { Penyuluhan sesuai } \\ \text { an } & \text { Kebutuhan petani } \\ \text { Pertanian } & \text { dalam 1 tahun }\end{array}$

\section{X.2.2}

Penerapan

Kunjungan

Penyuluhan dalam bentuk tatap muka

\section{X.2.3.}

Penerapan metode Penyuluhan dalam bentuk Demosnrtasi SL (dalam 1 tahun terakhir)

\section{X.2.4}

Penerapan metode Penyuluhan dalam bentuk temu temu (temu lapang, temu wicara, temu teknis, temu usaha) dalam 1 tahun terakhir

\section{X.2.5}

Penerapan

Kunjungan

Penyuluhan dalam bentuk Kursus (dalam 1 tahun terakhir)
Menyebarkan 1 judul, menyebarkan 24 judul, menyebarkan 5 - 7 judul menyebarkan 8 - 12 judul dan $\geq 60$ kali kunjungan , 45-59 kali kunjungan, 30-44 kali kunjungan 15-29 kali, kunjungan, < 15 kali kunjungan $\geq 3$ kali, 3 kali, 2 kali,1 kali dan

0 kali

\section{X.2.6.}

$\geq 3$ kali, 3 kali, 2 kali,1 kali dan

0 kali 


\section{Melakukan \\ Peningkatan \\ Kapasitas Petani \\ terhadap Akses \\ Infomasi Pasar dll. \\ X.2.7. \\ Menumbuhkan \\ kelompoktani/gapo \\ ktan dari aspek \\ kualitas dan \\ kuantitas}

\section{X.2.8.}

Meningkatkan

kelas kelompoktani

dari aspek kuantitas

dan aspek kualitas:

\section{2.9.}

Menumbuhkan dan mengembangkan

kelembagaan ekonomi petani dari aspek jumlah, dan kualitas

\section{2.10.}

Meningkatnya produksi komoditi unggulan di WKPP dibandingkan produksi sebelumnya

X3 X. 3.1.

Evalua Melakukan

si dan Evaluasi Pelaksaan

Pelapo Penyuluhan

ran Pertanian

\section{3.2.}

Membuat laporan pelaksanaan

Penyuluhan

Pertanian kerja antar petani,membangun

kemitraan,memandu membuat proposal

kegiatan serta Tidak melakukan

Tidak ada Penumbuhan, 1 Kelompok

Tani, 1 Gapoktan,

2 Kelompok Tani, Lebih dari 3

kelompok tani

Tidak ada peningkatan, dari

Kelompoktani BDK ke Pemula, dari

Kelompoktani Pemula ke Lanjut, dari

Kelompoktani Lanjut ke Madya, dari

Kelompoktani Madya ke Utama

Tidak terbentuk, BUMP yang berbentuk Perseroan Terbatas dan ber Badan Hukum, BUMP yang berbentuk Perseroaan Terbatas dan belum ber Badan Hukum, BUMP yang berbentuk Koperasi Tani, sudah ber Badan Hukum, BUMP yang berbentuk Koperasi Tani, belum ber Badan Hukum

$5 \%$ atau lebih, $4-<5 \%$, $3-<4 \%,-<3 \%,-<2 \%$

Sebanyak 1 kali, sebanyak 2 kali, sebanyak 3 kali, sebanyak 4 kali dan lebih dari 4 kali

Setiap Bulan, setiap Triwulan, Setiap Semester, setiap Tahun, setiap Semester \& Tahun 
Tabel 1: Variabel dan indikator manajemen penyuluh pertanian Sumber : SDM P Kementrian Pertanian RI

Untuk dapat mengambil suatu kesimpulan dari data yang diperoleh dalam pengolahan data digunakan metode internal yang didapat dari Permentan Nomor: 91/ Permentan/ OT.140/ 9/ 2013 kemudian dilakukan $\operatorname{Re}$ spesifikasi model dengan menggunakan Skala Likert's Summated Rating (LSR)

$\left.\begin{array}{cccc}\text { Sh } t_{1} & -S & T & h \\ \hline & h K & & \\ & =R & (L & K\end{array}\right)$

Skor tertinggi didapat dari perkalian antara nilai skor tertinggi dengan jumlah responden, yaitu 5 × $22=110$, sedangkan skor terendah didapat dari perkalian antara nilai skor terendah dengan jumlah indikator, yaitu $1 \mathrm{x}$ $22=22$. Dengan demikian range skor yang diperoleh adalah $(110$ - 22) / 5 = 17.6, maka;

o range skor 22 - 39, berkategori tidak baik ○ range skor 40-57, berkategori kurang baik
○ range skor 58-75, berkategori cukupbaik

○ range skor 76-93, berkategori baik

○ range skor 94-110,berkategori sangat baik Untuk melihat prestasi kerja penyuluh yaitu dengan menggunakan Jumlah pengukuran/ parameter sebanyak 16, setiap indikator dinilai dengan mengggunakan skala 1 sampai dengan 5. Skala 1 menunjukkan kinerja paling rendah dan skala 5 menunjukan kinerja paling tinggi. jumlah nilai seluruh pengukuran/parameter yaitu paling rendah 16 (jumlah pengukuran/ parameter $=16 \times 1$ ) dan paling tinggi 80 (jumlah pengukuran/ parameter $=16 \mathrm{X}$ 5). Jumlah nilai pengukuran/parameter yang diperoleh Penyuluh Pertanian disebut Nilai Evaluasi Mandiri (NEM) merupakan ukuran prestasi kerja Standar Nilai Prestasi Kerja (NPK) Penyuluh Pertanian dinyatakan dalam angka dan sebutan Tabel 2 berikut:

Tabel 2. Standar Nilai Prestasi Kerja (NPK) Penyuluh Pertanian.

\begin{tabular}{|c|c|c|}
\hline No & Nilai & Prestasi Kerja \\
\hline 1 & 91 keatas & Sangat Baik \\
\hline 2 & $76-90$ & Baik \\
\hline 3 & $61-75$ & Cukup \\
\hline 4 & $51-60$ & Kurang \\
\hline 5 & 50 ke bawah & Buruk \\
\hline
\end{tabular}

Sumber :Permentan No. 91/2013 
Tata Cara Perhitungan :

Rumus Perhitungan

$$
N=\frac{T \quad N}{B} \times 100
$$

NPK : Nilai Prestasi Kerja

NEM : Nilai Evaluasi Mandiri

\section{HASIL DAN PEMBAHASAN}

\section{Manajemen Penyuluhan Pertanian}

PenyelenggaraanPenyuluhan

berdasarkan Peraturan Menteri

PendayagunaanAparaturNegaraNo.:

PER/19/M.PAN/10/2008 Tentang Jabatan

Fungsional Penyuluh Pertanian dan Angka

Kreditnya menyebutkan bahwa

Penyelenggaraan Penyuluhan Pertanian meliputi:

1. Persiapan (Perencanaan)

2. Pelaksanaan

3. Evaluasi dan pelaporan

\section{Perencanaan}

Tabel 3. Perencanaan Persiapan Penyuluhan

\begin{tabular}{cccc}
\hline No & $\begin{array}{c}\text { Perencanaan } \\
\text { Penyuluhan }\end{array}$ & $\begin{array}{c}\text { Rata- } \\
\text { rata } \\
\text { skor }\end{array}$ & $\begin{array}{c}\text { Kate- } \\
\text { gori }\end{array}$ \\
\hline
\end{tabular}

Persiapan penyuluhan merupakan bagian penting sebelum pelaksanaan penyuluhan diselenggarakanguna mencapai tujuan penyuluhan yaitu perubahan perilaku, keterampilan dan pengetahuan petani. Persiapan tersebut antara lain melakukan Identifikasi potensi wilayah (IPW) dan Agroekosistem; Memandu penyusunan RDK dan RDKK, penyusunanprograma penyuluhan pertanianbersama tim dan penyusunanRKTPP.perencanaan penyuluhanpertanian dapat dilihat pada Tabel 3.

\begin{tabular}{llll}
\hline 1. & Data Potensi & 110 & SB \\
2. Pengawalan RDKK & 110 & SB \\
3. $\begin{array}{l}\text { Penyusunan } \\
\quad \text { Programa } \\
\quad \text { Penyuluhan } \\
\quad \text { Pertanian di desa dan }\end{array}$ & 101 & SB \\
4. $\quad$ kecamatan & & \\
$\quad$ Membuat & & \\
$\quad$ Penyuluhan & & \\
$\quad$ Pertanian & 110 & SB \\
Total Skor & & \\
Rata-rata X1 & $\mathbf{4 3 1 . 0 0}$ & \\
\hline
\end{tabular}
sumber :Data olahan,2018 
DariTabel3dalamperencanaan

persiapanpenyuluhandapat dilihat rata-rata skor 107,75 dengan kategori sangat baik (SB), variabel Perencanaan persiapan penyuluhan pertanian dinilai dari beberapa indikator yaitu telah melakukan perencanaan persiapan penyuluhan pertanian.

Pada indikator relevansi pendataan data potensi sesuai dengan indikator diperoleh skor 110 dengan katagori sangat baik (SB), pada indikator pengawalan RDKK memperoleh skor 110,00 dengan katagori sangat baik (SB), pada indikator Penyusunan programa penyelengaraan penyuluhan pertanian di desa dan kecamatan memperoleh skor 101, sedangkan indikator membuat Rencana Kerja Tahunan (RKT) Penyuluhan Pertanian memperoleh skor 110 dengan kategori sangat baik (SB).

\section{Pelaksanaan Penyuluhan.}

Berdasarkan hasil persiapan penyuluhan yang telah dilakukan, seperti tersedianya data potensi wilayah, rencana kegiatan dan kebutuhan kelompok sudah dan RKTPP telah tersusun, maka proses penyuluhan siap untuk dilaksanakan. Tanpa persiapan yang baik, pelaksanaan penyuluhan pertanian akan kehilangan arah dan tujuan.

Dalam pelaksanaannya, ada beberapa metode yang dapat diterapkan penyuluh pertanian agar dapat berjalan efektif dan efisien. Prinsipnya, dalam menentukan metodepenyuluhanperlu

mempertimbangkanantaralain:

a. Tujuanyangingindicapai(petani tahu, mau, mampu);b. isi pesan (umum/khusus); c. target sasaran (individu, kelompok, umum). d. dana yang tersedia.

Berdasarkan klasifikasinya, terdapat tiga metode penyuluhan yaitu metode penyuluhan media massa (TV, Radio, Lieflet dll), metode penyuluhan kelompok (demonstrasi/peragaan teknologi, kursus tani, sekolah lapang dll) dan metode penyuluhan individu (konsultasi pertanian), setiap metode 
Tabel 4. Pelaksanaan Penyuluhan Pertanian

\begin{tabular}{|c|c|c|c|c|}
\hline No & & Pelaksanaan Penyuluhan Pertanian & Skor & Kategori \\
\hline 1. & $\mathrm{X} 2.1$ & $\begin{array}{l}\text { Penyebaran materi Penyuluhan sesuai kebutuhan petani } \\
\text { (selama } 1 \text { tahun terakhir) }\end{array}$ & 108 & SB \\
\hline 2. & $\mathrm{X} 2.2$ & Penerapan kunjungan dlm bentuk tatap muka & 110 & SB \\
\hline 3. & $\mathrm{X} 2.3$ & $\begin{array}{l}\text { Penerapan metode Penyuluhan dalam bentuk demonstarsi } \\
\text { SL (selama } 1 \text { tahun terakhir) }\end{array}$ & 79 & B \\
\hline 4. & $\mathrm{X} 2.4$ & $\begin{array}{l}\text { Penerapan metode penyuluhan dalam bentik temu-temu } \\
\text { (temu lapang, temu wicara, temu teknis, temu usaha } \\
\text { (selama } 1 \text { tahun terakhir) }\end{array}$ & 83 & B \\
\hline 5. & $\mathrm{X} 2.5$ & $\begin{array}{l}\text { Penerapan metode penyuluhan dalam bentik kursus } \\
\text { (selama } 1 \text { tahun terakhir) }\end{array}$ & 87 & B \\
\hline 6. & $\mathrm{X} 2.6$ & $\begin{array}{l}\text { Melakukan peningkatan kapasitas petani terhadap akses } \\
\text { Informasi pasar dll }\end{array}$ & 106 & SB \\
\hline 7. & $\mathrm{X} 2.7$ & $\begin{array}{l}\text { Menumbuh dan mengembangkan kelembagaan ekonomi } \\
\text { pertani kwalitas dan kwantitas }\end{array}$ & 67 & CB \\
\hline 8. & $\mathrm{X} 2.8$ & $\begin{array}{l}\text { Meningkatkan kelas kelompok Tani dari aspek kwalitas } \\
\text { dan kwantitas }\end{array}$ & 93 & B \\
\hline 9. & $\mathrm{X} 2.9$ & $\begin{array}{l}\text { Menumbuhkan dan mengembangkan kelembagaan } \\
\text { ekonomi petani dari aspek jumlah dan kwalitas }\end{array}$ & 44 & KB \\
\hline 10. & $\mathrm{X} 2.10$ & $\begin{array}{l}\text { Meningkatkan produksi komoditi unggulan di WKPP } \\
\text { dibandingkan produksi sebelumnya }\end{array}$ & 91 & B \\
\hline \multicolumn{3}{|c|}{ Total Skor } & 868 & B \\
\hline \multicolumn{3}{|c|}{ Rata-rata X2 } & 86,80 & B \\
\hline
\end{tabular}

Sumber : Data Olahan, 2018

menjelaskan bahwa pelaksaan penyebaran materi sesuai dengan kebutuhan petani telah berjalan dan telah menyebarkan materi penyuluhan sesuai kebutuhan petani diatas 12 judul/topik, penyampaian materi dalam berbagai bentuk, sesuai dengan karaktristik wilayah binaan masing-masing penyuluh, media penyampain materi dapat berbentuk media cetak, media audio visual dan media internet, leaflet dan brosur, (Permentan Nomor 52/0T/140/12/2009 tentang metode penyuluh pertanian dalam menyampaikan, tujuannya adalah mempermudah penyampaian sehingga petani mau menerima, mempelajari dan menerapkan materi penyuluhan, khususnya dalam pengelolaan usahataninya.

Indikator penerapan kunjungan dalam bentuk tatap muka mendapat skor 110,00 dengan katagori sangat baik (SB), ini menjelaskan bahwa penerapan kunjungan dengan bentuk tatap muka mendapat skor 
yang tinggi, dalam hal ini penyuluh telah malakukan kunjungan dengan metode tatap muka diatas 60 kali dalam setahun dengan standar kunjungan ke kelompok tani adalah minimal 8 kali dan maksimal 16 kali pertemuan dalam 1 bulan. Pertemuan tatap muka wajib dilakukan oleh seorang penyuluh dengan Sistem Latihan dan Kunjungan (LAKU), dengan interval waktu 2 (dua) minggu sekali, namun dikarenakan jumlah desa binaan dan kelompok tani binaan penyuluh yang melebihi kapasitas seorang penyuluh yang rata-rata membina 4-5 desa per-penyuluh dan kelompok binaan mencapai 34 kelompok, hal ini yang membuat ada kelompok-kelompok tani yang tidak tersentuh sama sekali oleh penyuluh, namun secara beban tanggung jawab kerja yaitu melakukan kunjungan diatas 60 kali dalam setahun telah terlaksana dengan sangat baik.

Indikator penerapan metode penyuluhan dalam bentuk demontrasi sekolah lapang (SL) kurun waktu 1 tahun terakhir mendapat skor 79.00 dengan katagori baik (B). Ini menunjukkan bahwa telah melaksanakan metode penyuluhan dalam bentuk Sekolah Lapang (SL) rata-rata 2 kali dilaksanakan. Sesuai standar pelaksanaan Sekolah Lapang (SL) yaitu anatara 1 sampai denga 3 kali dalam 1 tahun, mengingat Sekolah Lapang membutuhkan biaya yang besar untuk dapat dilaksanakan.

Indikator penerapan metode penyuluhan dalam bentuk temu-temu baik temu lapang, temu wicara, temu teknis, temu usaha dalam 1 tahun terakhir mendapat skor 83,00 dengan katagori baik (B), ini menjelaskan bahwa penerapan metode temu-temu telah dilakukan rata-rata 3 kali dalam setahun.Penerapan metode ini pada umumnya berada pada posisi baik, sama dengan sekolah lapang, penerapan metode temu-temu juga berada pada kisaran 1-3 kali dalam 1 tahun. Karena metode temutemu juga hanya dilaksanakan apabila ada dana dan difasilitasi oleh pemerintah dengan anggaran yang tersedia baik dari dana APBD maupun dana APBN melalui dana Dekonsentrasi (yaitu dana APBN yang dilaksanakan oleh Gubernur sebagai wakil pemerintah).

Indikator penerapan metode penyuluhan dalam bentuk kursus dalam kurun waktu 1 tahun terakhir mendapat skor 87.00 dengan katagori baik (B). Ini menunjukkan bahwa penyuluh pertanian telah menerapkan metode penyuluhan dalam bentuk kursus tani, untuk metode ini rata-rata hanya dilaksanakan 3 kali. Indikator ini juga sama halnya dengan sekolah lapang, hanya dapat dilaksanakan jika ada program dinas atau anggaran untuk pelaksanaan kursus tersebut, karena 
pelaksanaan kursus tani membutuh anggaran untuk media penyuluhan, ATK dan sarana lainnya.

Indikator peningkatan kapasitas petani terhadap akses informasi pasar mendapat skor 106,00 dengan katagori sangat baik (SB) disini menunjukkan bahwa peran penyuluh dalam memberikan informasi pasar terhadap petani dan pelaku usaha telah berjalan sebagaimana yang diharapkan, yaitu memberikan informasi dan menunjukkan sumber informasi, seperti informasi mengenai harga penjualan TBS sesuai dengan harga petunjuk pemerintah melalui dinas perkebunan dan organisasi-organisasi berkaitan dengan sumber harga TBS, membangun jejaring kerja antar petani, adalah mengupayakan hubungan antara petani wilayah binaan dengan petani yang berada didaerah lain, membangun kemitraan adalah mengajak dan mengarahkan petani untuk membagun kemitraan dengan pengusaha dan petani sukses, memandu membuat proposal kegiatan, membanu petani dalam membuat proposal baik kepada Instansi Pemerintah Kabupaten, Pemerintah Provinasi dan Pemerintah Pusat, serta proposal kepada perusaaan yang berada disekitar wiayah binaan masing-masing.

$$
\text { Pada indikator menumbuhkan }
$$
kelompok tani/ Gabungan kelompok tani
(Gapoktan) dari aspek kualitas dan kwantitas mendapakan skor 67,00 dengan katagori cukup baik (CB), perolehan skor cukup baik dikarenakan pada wilayah binaan penyuluh pertanian rata-rata sudah memiliki banyak kelompok tani, sehingga akses untuk pembentukan baru jarang dilakukan, rata-rata hanya menumbuhkan1Gapoktan.

Pembentukan Kelompok tani dan Gapoktan harus sesuai dengan kebutuhan dan kondisi lapangan.

Indikator meningkatkan kelas kemampuan kelompok tani dari dari aspek kwalitas dan kuantitas memperoleh skor 93,00 dengan katagori baik (B) indikator ini menjelaskan bahwa rata-rata penyuluh pertanian telah mampu meningkatkan kelas kelompok tani rata-rata 3 kelompok tani, yaitu peninggkatan kelas kelompok tani dari kelas Pemula ke kelas Lanjut, dari kelas Lanjut ke kelas Madya dan dari kelas Madya ke kelas Utama, Dasar pelaksnaan penilaian kelompok tani adalah Peraturan Menteri Pertanian Nomor 82/Permentan/ OT.140/ 8/2013 Tahun 2013 tentang Pedoman Pembinaan Kelompok Tani dan Gabungan Kelompok Tani, Klasifikasi kemampuan kelompok tani merupakan pemeringkatan kemampuan kelompok tani yang terbagi menjadi 4 (empat) kategori : 1) Kelas Pemula $(0-250)$, 2.Kelas 
Lanjut (251 - 500), 3) Kelas Madya (501 750) dan 4) Kelas Utama (751 - 1.000).

Pada indikator menumbuh dan mengembangkan kelembagaan ekonomi petani dari aspek kwalitas dan kwantitas mendapatkan skor 44,00 dengan kategori kurang baik $(\mathrm{KB})$ indikator ini memperoleh skor yang rendah dikarenakan penyuluh belum bisa menumbuh dan mengembangkan kelembagaan ekonomi petani dalam 1 tahun terakhir, berupa BUMP yang berbentuk Perseroan Terbatas dan sudah berbadan hukum, BUMP yang berbentuk Perseroan Terbatas dan belum berbadan hukum, BUMP yang berbentuk Koperasi Tani sudah berbadan hukum dan BUMP yang berbentuk Koperasi Tani belum berbadan hukum, hal ini terjadi karena kelembagaan ekonomi pada umumnya telah terbentuk pada tahun sebelumnya. Indikator ini juga tidak dapat diterapkan pada tiap tahun, karena pembentukan dan pengembangan telah dilakukan pada tahun-tahun sebelumnya.

Indikator meningkatkan produksi komoditi unggulan diwilayah Kerja Penyuluh Pertanian (WKPP) dibandingkan dengan produksi sebelumya mendapatkan skor 91,00 dengan katagori baik (B), dilihat dari skor tersebut rata-rata penyuluh telah mampu meningkatkan produksi komoditi unggulan dengan persentase yang bervariasi mulai dari $4 \%$ sampai dengan $5 \%$. Komoditi unggulan tersebut akan berbeda pada setiap wilayah binaan, baik itu peningkatan produktivitas tanaman padi sawah, padi gogo, jagung, sayur-sayuran, kelapa sawit, karet, kakao dan lain-lain.

\section{Evaluasi dan Pelaporan}

Evaluasi merupakan kegiatan yang tidak terpisahkan dalam proses penyuluhan, evaluasi penyuluhan sangat penting untuk mengukur/menilai sejauh mana tingkat keberhasilan kegiatan penyuluhan yang telah dilaksanakan. Dalam proses evaluasi, ada beberapa aspek yang perlu diperhatikan seperti apakah ada perubahan pengetahuan, prilaku dan sikap petani, bagaimana sarana dan prasarana yang tersedia, sudah tepatkah metode penyuluhan yang digunakan dan lain sebagainya. Untuk itu, sebelum melakukan evaluasi perlu ditetapkan indikator-indikator terkait apa yang akan dievaluasi dalam pelaksanaan penyuluhan

Untuk Evaluasi dan Pelaporan Pelaksanaan Penyuluhan Pertanian dapat dilihat pada Tabel 5. 
Tabel 5.EvaluasidanPelaporan pelaksanaan Penyuluhan Pertanian

\begin{tabular}{ccccc}
\hline No. & Evaluasi dan Pelaporan & Skor & $\begin{array}{c}\text { Kate- } \\
\text { gori }\end{array}$ \\
\hline 1. & X3.1 & $\begin{array}{c}\text { Melakukan evaluasi pelaksanaan penyuluhan } \\
\text { pertanian }\end{array}$ & 86,00 & $\mathrm{~B}$ \\
& & $\begin{array}{c}\text { Membuat laporan pelaksanaan penyuluhan } \\
\text { pertanian }\end{array}$ & & \\
2. & & & \\
& & & 71,00 & $\mathrm{~KB}$ \\
& & & & \\
& & $\begin{array}{c}\text { Total Skor } \\
\text { Rata-rata X3 }\end{array}$ & $\mathbf{1 5 7 , 0 0}$ & B \\
& & &
\end{tabular}

sumber :Data olahan,2018

Evaluasi dan Pelaporan atas pelaksaan penyuluhan pertanian dilaporkan secara berkala mulai dari bulanan, triwulan, semester dan tahunan kepada Dinas Pertanian dan Perikanan Kabupaten Indragiri Hulu melalui Balai Penyuluhan Pertanian dan Perikanan dimasing-masing kecamatan, pada indikator melakukan evaluasi pelaksanaan penyuluhan pertanian pada wilayah kerja masing-masing mendapatkan skor 86,00 dengan katagori baik (B). Rata-rata penyuluh pertanian telah melakukan evaluasi atas pelaksanaan penyuluhan pertanian dilapangan rata-rata 3 sampai 4 kali evaluasi.

Indikator pembuatan laporan pelaksanaan penyuluhan pertanian dengan skor 71,00 dalam katagori kurang baik (KB) hal ini disebabkan rata-rata penyuluh pertanian hanya membuat laporan 2 sampai 3 kali dalam 1 tahun. Disisi lain, sering kali dijumpai sistem pelaporan yang terlalu beragam dan terinci sehingga menyita banyak waktu dan mengganggu kelancaran kegiatan penyuluhan itu sendiri. Perubahan sistim pelaporan itu sendiri sering terjadi sesuai dengan kebijakan pada dinas yang menangani penyuluhan. Membuat laporan sesuai standar yaitu Laporan Bulanan, Laporan Triwulan, Laporan Semester dan Laporan Tahunan.

\section{Hasil Prestasi Kerja}

Berdasarkan tujuan kedua penelitian yaitu untuk mengetahui Prestasi Kerja Penyuluh Pertanian dalam Merencanakan, Melaksanakan dan Mengevaluasi Program Penyuluhan di Kabupaten Indragiri Hulu dilakukan analisis deskriptif dan skoring. Pengukuran kinerja Penyuluh Pertanian Lapangan berdasarkan Permentan No 91 Tahun 2013 tentang Pedoman Evaluasi Kinerja Penyuluh Pertanian yaitu dengan melihat bagaimana pelaksanaan kinerja penyuluh pertanian lapangan. indikator yang digunakan untuk melihat kinerja Penyuluhan Pertanian Lapangan yaitu Persiapan 
Penyuluhan Pertanian, Pelaksanaan Penyuluhan Pertanian, dan Evaluasi dan Pelaporan. Semua indikator tersebut berisikan 16 pertanyaan. Setiap pertanyaan dinilai dengan menggunakan skala 1 sampai dengan 5Skala 1 menunjukkan kinerja paling rendah dan skala 5 menunjukkan kinerja paling tinggi

Penilaian kinerja penyuluh pertanian dilakukan untuk meberikan masukan terhadap hasil kerja atau prestasi kerja yang diperoleh penyuluh pertanian yang akan memberikan umpan balik terrhadap tujuan dan sasaran kinerja, perencanaan dan proses pelaksanaan kinerja penyuluhan pertanian. Hasil penelitian prestasi kerja Penyuluh Pertanian Lapangan di Dinas Pertanian dan Perikanan Kabupaten Indragiri Hulu dapat dilihat pada Tabel 6 
Tabel 6; Hasil Penelitian Rata-rata prestasi kerja penyuluh pertanian lapangan Dinas Pertanian dan Perikanan Kabupaten Indragiri Hulu tahun 2018

\begin{tabular}{|c|c|c|c|c|c|c|}
\hline \multirow[t]{3}{*}{ No } & \multicolumn{3}{|c|}{ Indikator Kinerja Penyuluh Pertanian Lapangan } & \multirow{3}{*}{$\begin{array}{l}\text { Total } \\
\text { NEM }\end{array}$} & \multirow{3}{*}{$\begin{array}{c}\text { NPK } 5 \times 80 / \\
100\end{array}$} & \multirow{3}{*}{$\begin{array}{l}\text { Tingkat } \\
\text { Kinerja }\end{array}$} \\
\hline & Persiapan & Pelaksanaan & Evaluasi & & & \\
\hline & & & Pelaporan & & & \\
\hline 1 & 2 & 3 & 4 & 5 & 6 & 7 \\
\hline 1 & 20 & 41 & 7 & 68 & 85 & Baik \\
\hline 2 & 19 & 38 & 7 & 64 & 80 & Baik \\
\hline 3 & 19 & 38 & 7 & 64 & 80 & Baik \\
\hline 4 & 19 & 37 & 7 & 63 & 78 & Baik \\
\hline 5 & 19 & 35 & 10 & 69 & 80 & Baik \\
\hline 6 & 19 & 37 & 7 & 63 & 78 & Baik \\
\hline 7 & 20 & 44 & 7 & 71 & 88 & Baik \\
\hline 8 & 20 & 42 & 7 & 64 & 86 & Baik \\
\hline 9 & 20 & 41 & 7 & 68 & 85 & Baik \\
\hline 10 & 20 & 41 & 6 & 67 & 83 & Baik \\
\hline 11 & 20 & 41 & 6 & 67 & 83 & Baik \\
\hline 12 & 20 & 43 & 6 & 69 & 86 & Baik \\
\hline 13 & 20 & 38 & 6 & 64 & 80 & Baik \\
\hline 14 & 20 & 40 & 7 & 67 & 83 & Baik \\
\hline 15 & 20 & 39 & 7 & 66 & 82 & Baik \\
\hline 16 & 20 & 40 & 6 & 66 & 82 & Baik \\
\hline 17 & 19 & 37 & 10 & 66 & 82 & Baik \\
\hline 18 & 19 & 39 & 8 & 66 & 82 & Baik \\
\hline 19 & 20 & 41 & 7 & 68 & 85 & Baik \\
\hline 20 & 19 & 38 & 8 & 65 & 81 & Baik \\
\hline 21 & 19 & 39 & 7 & 65 & 81 & Baik \\
\hline 22 & 20 & 39 & 7 & 66 & 82 & Baik \\
\hline Jml & 431 & 868 & 157.00 & 1.456 & 1.82 & \\
\hline Rata2 & 107,5 & 86,80 & 7.1 & 66,18 & 82,73 & \\
\hline
\end{tabular}

Sumber :data olahan, 2018

Berdasarkanindikatorpersiapan

penyuluhanan,pelaksanaanpenyuluhan

rata-rata 82,72. Hal tersebut dikarenakan penyuluh pertanian

sepenuhnyasudahmembuatdatapotensi

wilayah dan agroekosistem berupa adanya pertanian dan evaluasi penyuluh pertanian KabupatenIndragiri Hulu sudah dikategorikan baik (B) dengan perolehan nilai peta wilayah binaan, peta dan potensial wilayah binaan, adanya rencana jadwal kegiatan penyuluhan dimasing-masing wibi. penyuluh pertanian juga selalu membuat 
RKTPP secara bersama-sama. Selain hal tersebut penyuluh pertanian juga ikut berperan aktif berupa bimbingan dalam penyusunan RDKK (Rencana Defenitif Kebutuhan Kelompok) kepada setiap kelompok tani yang berada dalam wilayah binaan penyuluh pertanian.

Dari segi penyebaran materi penyuluhan materi sesuai kebutuhan petani, penerapan kunjungan dalam berbagai metode telah terlaksana dengan baik. Melaksanakan peningkatan kelas kelompok tani, menumbuh kembangkan dan upaya peningkatan produktivitas komoditi unggulan diwilayah binaan masing-masing telah dilaksanakan, namun belum mencapai nilai maksimal, hal ini disebabkan masih adanya kendala-kendala dalan pelaksnaannya, masih minimnya peningkatan kelas kelompok tani, karena petani masih belum mandiri dan ketergantungan pada bantuan pemerintah, serta kurangnya instrument yang disiapkan oleh pemerintah daerah sebagai dasar penilai kelompok tani.

Sedangkan evaluasi dan pelaporan juga sudah berjalan dengan baik, artinya belum sepenuhnya dilaksanakan, hal ini dikarenakan masih ada penyuluh yang kurang mampu dalam membuat laporan sesuai dengan standar yang telah ditetapkan dan masih kurangya fasilitas pelaporan disetiap (BP3), seperti sarana Computer, Alat Tulis Kantor
(ATK), jaringan intenet namun secara umum rata-rata sudah memperoleh kategori baik (B) dilihat dari Nilai Prestasi Kerja (NPK)

\section{KESIMPULAN DAN SARAN}

Adapun kesimpulan dari hasil penelitian adalah sebagai berikut;

1. Manajemen kinerja penyuluh pertanian Dinas Pertanian dan Perikanan Kabupaten Indragiri Hulu memiliki nilai dengan katagori baik dengan skor 91,02 (X), untuk persiapan perencanaan (X1) memiliki skor 107,75 dengan katagori sangat baik (SB), sedangkan pelaksanaan penyuluhan pertanian (X2), Evaluasi dan pelaporan masing-masing memiliki skor 86,50 dan 78,50 dengan kategori baik (B)

2. Tingkat prestasi kerja penyuluh pertanian dalam merencanakan, melaksanakan, evaluasi dan pelaporan pelaksanaan penyuluhan pertanian Dinas Pertanian dan Perikanan Kabupaten Indragiri Hulu, memiliki prestasi kerja Baik, dengan nilai rata-rata 82,73

\section{Saran}

Berkaitan dengan hasil penelitian dapat disarankan hal-hal sebagai berikut.

1. Pada pelaksanaan penyuluhan, penyuluh perlu meningkatkan kenerja dalam menumbuh dan mengembangkan kelembagaan ekonomi petani dari Kelompok tani, Gapoktan menjadi koperasi. 
2. Penyuluh harus membuat laporan secara berkala, yaitu dalam bentuk laporan bulanan, triwulan, semester dan tahunan, sehingga akan memudahkan dalam penilaian kinerja penyuluah oleh pimpinan sebagai bahan evaluasi program pemerintah dibidang pertanian.

\section{DAFTAR PUSTAKA}

2003. Redefinisi dan Revitalisasi Penyuluhan Pertanian. Pusat Pengembangan Agrobisnis dan Perhutanan Sosial. Surakarta.

Anonimous, 1999. Pedoman Monitoring dan Evaluasi Penyuluhan Pertanian. Departemen Pertanian Pusat Penyuluhan Pertanian. Jakarta

Bahua Muhamad I, 2016. Kinerja Penyuluh Pertanian. Deepublish Yogjakarta

BPS Inhu, 2018. Kabupaten Indragiri Hulu dalam Angka, Nomor Publikasi/Publication Number : 14020.1803.

BPSDM-Pertanian Kementerian Pertanian 2016. Pedoman Pelaksanaan Evaluasi Kinerja Penyuluh Pertanian, Pusat Penyuluhan Pertanian.

Fathoni, 2006, Manajemen Sumber Daya Manusia, Bandung : Rineka Cipta.

Kartasapoetra. 1991. Teknologi Penyuluhan Pertanian. Jakarta: Bumi Aksara.

Mardikanto T. 1993. Penyuluhan Pembangunan Pertanian. Surakarta: Sebelas Maret University Press.

Mardikanto T. 2009. Sistem Penyuluhan Pertanian. Surakarta: Lembaga Pengembangan Pendidikan (LPP) UNS dan UPT Penerbitan dan Pencetakan UNS (UNS Press).

Pemkab Inhu, 2016. Perda Nomor 4 tahun 2016 tentang Pembentukan dan Susunan Perangkat Daerah Kabupaten Inhu.

Peraturan Menteri Pertanian Nomor 91/Permentan/OT.140/9/2013 Tentang Pedoman evaluasi kinerja penyuluh pertanian. Deptan RI.

Rifai, MA 2000. Reorientasi Penyuluhan Pertanian, Prasayarat Pertanian Kerakyatan. Sinar Tani, 28 Juni-4 Juli 1999 No. 2848 Tahun XXX.

Setiana,L. 2005. Teknik Penyuluhan dan Pemberdayaan Masyarakat. Penerbit ANDI Yogyakarta. 137 hal.

Sevilla CG. 1993. Pengantar Metode Penelitian. Jakarta: Universitas Indonesia Press

Sumardjo. 1999. Disertasi Transformasi Model Penyuluhan Pertanian Menuju Pengembangan Kemandirian Petani. (kasus di Propinsi Jawa Barat) 1999

Susanti M, Rosnita, Roza Y. 2016, Analisis Kinerja Lembaga Penyuluhan di Kabupaten Indragiri Hulu, Jurnal Ilmiah Pertanian Vol, 13 No. 2. hal 2337.

Undang-Undang Republik Indonesia Nomor 16. 2006. Sistem Penyuluhan Pertanian, Perikanan, dan Kehutanan. 
Jurnal Agri Sains Vol, 3 No.01, (29 Juni 2019) 